\title{
Social Intelligence and Employee Commitment in Bayelsa State Health Sector
}

\author{
Jasmine Okponanabofa Tamunosiki-Amadi, PhD \\ Godwill Duke Sele \\ Omiloli Elia Ernest \\ Department of Business Administration \\ Faculty of Management Sciences \\ Niger Delta University Wilberforce Island, Amassoma \\ Nigeria
}

\begin{abstract}
This study examined the relationship between Social Intelligence and Employee Commitment in the health sector in Nigeria. The research design adopted for this study is cross sectional survey design. A total 339 questionnaires were distributed out of which 313 were retrieves of which 273 was found useable. The study employed the Taro Yamen's technique to arrive at the sample size of 339 Spearman's Rank Order correlation coefficient was used for the bivariate analysis and partial correlation was used for the multivariate analysis with the aid of SPSS 20.0. The findings revealed a highly significant level of relationship between the dimension (clarity) of Social Intelligence and the measures (affective, continuance and normative commitment) of Employee Commitment. In conclusion the study found out that social intelligence influences employee commitment and this enhances outcomes such as maintaining high performance standards and achieving high performance goals.
\end{abstract}

Keywords: Social Intelligence, Employee Commitment, Clarity, Affective Commitment, Continuance Commitment, Normative Commitment

\section{Introduction}

The complicatedness of societal processes, increase of competition, advancement of science and technology, the increase of demands and the development of organizations require that efficient and skilled managers and committed employees be employed for optimal performance. Previous studies point to "I don't care" mindset among public sphere personnel (Okpara, and Wynn, 2008). This mind-set is likened with lack of commitment in the public sphere in Nigeria (Bambale, Shamsudin, and Subramaniam, 2012). However how to raise employee commitment as well as heighten their productivity has become one of the challenges faced by organizations in recent times (Akinbode \& Oni, 2012; Coetzee \& Botha, 2012). Researchers in Nigeria have began to explore the issues of commitment at workplace including hospitals (Igbenegbu \&Popoola 2011; Ahiauzu., 2012).

Social Intelligence is the ability to build relationships with others having interpersonal know-how, ability to evaluate others feelings, temperaments and incentives, ability to sympathize and being skilled in deciphering nonverbal signals. It's been noticed that before personnel are recruited into an organization, the potential personnel are made to take series of checks and interviews. All these interviews and checks administered are usually based on the intelligent Quotient of the potential employees, not much is done to determine the social intelligence level of the employees leaving the organization with so many employees who are exceptionally intelligent but are lagging in social intelligence. This may be the reason for low employee/employer and employee/customer relationships which can likely lead to high employee turnover and low commitment. Social intelligence is a highly essential factor in an organization for the employer and employee. If an organization is constituted of socially intelligent people, the tendency is that employees become motivated to do their jobs, remain in the organization and become committed to their jobs.

Saxena and Jain (2013) studied "social intelligence of graduate college students in relation to their gender and subject stream in Bhilai city in India; Ebrahimpoor, Zahed and Elyasi (2013) examined the study of relationship between social intelligence and organizational performance (case Study: Ardabil regional water company's managers) in Ardabil, Iran; Jug (2015) investigated personality traits, social intelligence, social support and juvenile delinquency in Slovenia; Dhanda and Ninaniya (2017) investigated dimensions of social intelligence of adolescents in Panipat district of Haryana nation in India; Eketu and Edeh(2015) studied the relationship between social intelligence and employee intention to stay in Port Harcourt city Nigeria; Yermentataeeyeva, Uaidullakyzy and Ayapbergenova (2013). 
Investigated social intelligence as a condition for the development of communicative competence of the future teachers in Khazakh National Pedogogical University and Kazakhstan state University in Kazakhstan; Vasina and Bagel (2010) investigated social intelligence as a predictor of pro-social asocial behavior: ways of affecting it through psychotherapy and social and pedagogical programmes in Brunensis

With all the studies carried out by various scholars, little or no attention has been made on the variables of Social Intelligence and Employee Commitment in the health sector of Nigeria. This has created a literature gap. It's on this backdrop that this study is built on. Hence, the knowledge gap for this study is to examine social intelligence and employee commitment within the health sector of Nigeria, specifically Federal Medical Centre Yenagoa Bayelsa State Nigeria.

Figure 1: Conceptual Model on Social Intelligent and Employee Commitment

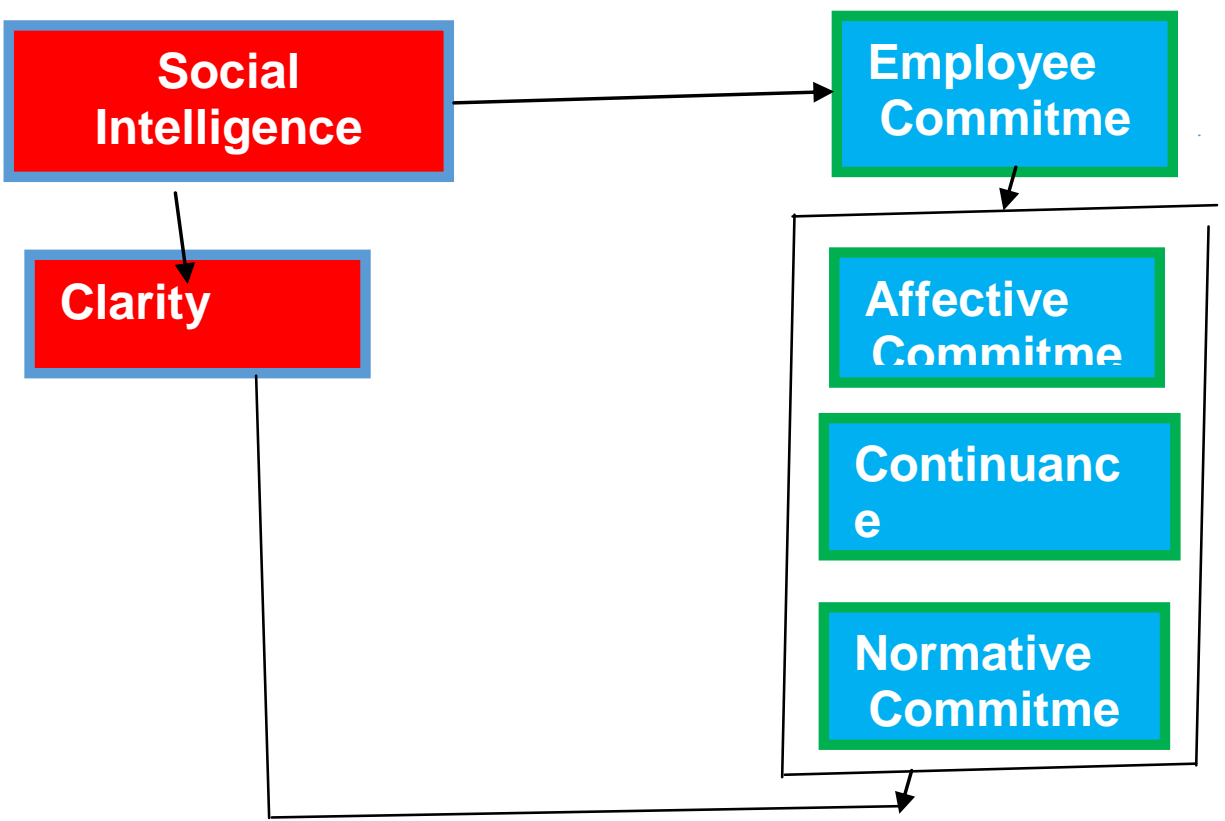

Source: Researcher's Desk Conceptualization (2019).

The conceptual model above shows the dimension of Social Intelligent and measures of Employee Commitment which includes Clarity, Affective, Continuance and Normative Commitment respectively. The conceptual framework indicates the possible relationship existing between the constructs in the study.

\section{Literature Review}

\subsection{Social Intelligence}

Edward Thorndike (1920) coined the term Social Intelligence in his Harper monthly magazine where he described social intelligence as the ability to understand and manage men and women, boys and girls, to behave wisely in human relations. It is a fundamental ingredient in what makes people succeed in life. People who are high in social intelligence can interact effectively with their environment. Sameer Babu, (2007). Thorndike divided intelligence into 3 distinct parts:- Social intelligence or ability to understand and deal with persons. Concrete Intelligence or capacity to understand and deal with the things as in skilled trades and scientific appliances. Abstract intelligence or ability to understand and deal with verbal and mathematical symbols. Thorndike (1920)'s definition was accepted by researchers and used for several years until in 1983 Harvard Professor Howard Gardner proposed the theory of multiple intelligences in social sciences. He indicated that human intelligence is composed of a range of interwoven competences or different 'intelligences' instead of the earlier idea of being merely a single trait referred as 'IQ' (intelligent quotient). He identified these multiple intelligences as abstract intelligence which he called symbolic reasoning, practical intelligence he called as getting things done and emotional intelligence he described as selfawareness and self-management, aesthetic intelligence which he identified as sense of music, art design, form and literature, kinesthetic intelligence he described as skills of the body use in sports, dance or movement of machines, like flying airplanes or driving cars and lastly social intelligence which he described as the ability of dealing with people (Cantor \&Kilhstrom, 2011). 
He described social intelligence as the capability to know oneself and to understand others is an inalienable part of the human conditions as is the ability to recognize objects or sounds, and it deserves to be investigated no less than these other "less charged "forms.

Social Intelligence (SI) has become an interesting area of research over the years as it has drawn the attention of researchers in various fields today because the essence of interpersonal relationships in work environment has been emphasized. Over the years, social intelligence has been defined in several ways helping future researchers to understand the multi-dimensional aspect of the construct which earlier researchers understood as cognitive, social intelligence (ie, social perception or the ability to decode verbal and non-verbal behaviors of others) and behavior social intelligence (ie, effectiveness in social situations; Lievens and Chan, 2008). As empathy started to be understood as being part of social intelligence, the affective component of social intelligence was added. This affective component is a significant part of Daniel Goleman \& Karl Albretch's (2006) theory of social intelligence.

Goleman, (2006) has drawn on social neuroscience research to propose that social intelligence comprises of social awareness (inclusive of empathy, attunement, emphatic accuracy and social cognition) and social facility (together with synchrony, self-presentation, influence and concern). Goleman's research intimates that our social relationships have effect on our physical well-being. The upshot includes blood flow, respiration, moods such as fatigue and depression and weakening of the immune system. Social intelligence is the capability to handle composite social relationships and environment efficaciously. Albrecht, (2006) defines Social Intelligence as the ability to get along easily with others and to get them to cooperate with you which he named the New Science of Success. He developed a set of dimensions which can be used for defining, measuring and developing Social intelligence of which he categorically stated that he "makes no claims for the statistical validity or psychometric rigor of this model or these dimensions, other than that they seem to pass the test of common sense. It will, of course, have to stand or fall on its merits over time." These dimensions are situational awareness, presence, clarity, authenticity and empathy. This study will examine situational awareness, clarity and empathy as dimensions of social intelligence.

\subsubsection{Clarity}

Albretch, (2006) defines clarity as the ability to convey one's thoughts, opinions, ideas, and intentions plainly; to perceive the power of language as a medium of idea and expression, and to apply language as a strategic asset. He pointed out that people with eminent Social Intelligence clarity have mastered the potential to move from a "sky-high" degree of abstract verbal communication to a ground or concrete degree. They are capable of piloting a "verbal helicopter' deciding on phrases, figures of speech, expression, analogies, and metaphors that sets the listener's reasoning process at the desired altitude, being capable of conveying their listeners all the way down to the lowest level of detail or up to the most eminent degree of generality. In addition it is the ability to monitor one's own language pattern and that of others to avoid conflicts which may develop. Brinkert, (2010) communication is required not merely for transmission of information and knowledge to one another, but more importantly to inter-relate as humans worldwide. Communication is done in every sphere of life, i.e. in relationships, households, enterprises, countries, and so on. Vessey, DeMarco and DeFazio, (2010) opined that the 'how what, why and where' of the choice of communication could either harm or edify us. Raya, (2006) stated that what one says, how one says it, what one mean by it are very important and could be life-changing.

Communication requires the transmission of verbal and non-verbal messages which is made up of a sender, a receiver and a channel of communication. It is important that an agreement exists within verbal and nonverbal communication. Verbal Communication consists of spoken and written words which people use to convey ideology. According to Lambrini and Loanna (2014), words convey only a portion of the message being communicated; while attitude, the pitch of one's voice, and the movement of one's body convey the rest. Evans, (2003) in addition posited that non-verbal communication is an ongoing action that happens without even being recognized. Berengere, (1997) posited that a bulk of non-verbal communication modes and interpretations are dependent on the unique cultural custom of the communicator and the receiver, respectively. The clarity of the message may be distorted in the process of transmitting; this is often referred to as barriers. Effective communication is not unidirectional. Berengere, (1997) supports that effective communication is a two-way dialogue where both parties speaks and are as well listened to without either interrupting, both ask questions for clarity, express opinions and interchange information, and both are able completely to grasp and understand what others mean to say.

\subsection{Employee Commitment}

Employee commitment is essential because high degree of commitment result in several favorable organizational outcomes. It manifests the magnitude to which employees identify with an organization and is committed to its goals. BiljanaDordevic, (2004) stated that the commitment of employees is a significant subject because employee's performance, absenteeism turnover and other behaviors can be predicted by it. 
Gutierrez, Candela, and Carver (2012) stated that committed employees who are highly motivated to contribute their time and energy to the pursuit of organizational goals are increasingly recognized as the chief asset useable in an organization. Allen and Meyer (1991) discussed commitment in their article "Three component model of commitment" and posited that three distinct types of employee commitment exist. These three components are affective commitment, continuance commitment and normative commitment.

\subsubsection{Affective Commitment}

According to Allen and Meyer (1990) affective commitment occurs when an employee has a strong emotional bond to the organization and to the work they do. They identify with the organization's goals and values and genuinely want to be there. Affective commitment is concerned with three main aspects namely: (1) the development of psychological affinity to a firm; (2) association with the organization; (3) the bid to continue as a member of the organization. Individuals, by building up emotional affinity toward a firm tend to connect themselves with the objectives of the firm and support the firm in achieving these objectives (Allen \& Meyer, 1990). When the employees' personal values are uniform with the organization's values, then the employees can identify with the organization, and this will enable the individuals to assimilate the values and goals of the organization. Affective commitment has been tied to a wide range of positive upshots relative to absenteeism, turnover, organizational behavior and job performance (Meyer \&Herscovitch, 2001). Organizations can obtain positive results through affective commitment through reduced absenteeism, reduced turnover, better organizational behavior and organizational effectiveness.

\subsubsection{Continuance Commitment}

It involves the need to stay in an organization because of accrued 'side-bets' and sometimes the lack of substitute employment opportunities. (Becker 1960). Hrebiniak and Allutto(1972) definition of commitment "is a result of individual-organizational transactions and alterations in side-bets or investments over time." Side-bets pertain to significant things that an employee has put in place over time such as money that would be forfeited or devalued if the employee leaves the organization, effort or time that has been put in over the years (Meyer \& Allen 1984). Morris and Sherman asserted that continuance commitment is the outcome of inducements and contributions within an organization and an employee. It was also observed that accumulation of side-bets increases commitment of employees, since it becomes more costly to leave an organization when the side-bets increase.

\subsubsection{Normative Commitment}

Normative commitment is defined as the feeling that an employee has to remain in an organization on account of personal norms and values. Normative commitment renders an awareness of moral duty or obligation and is connected with the internalization of the organization's norms and values, and adoption of its goals and mission (Iles, Forster and Tinline, 1996). Normative commitment develops primarily based on previous knowledge or influence by for example family based experiences (parents that emphases work loyalty), or cultural experiences (sanctions opposed to jobhopping) (Allen \&Meyer 1996). Normative commitment can build up via beliefs that the employees have, that employers offer more than they can give. The normative elements increase as employees' belief in their ethical responsibility to stay with a particular organization, disregarding whatever position melioration or accomplishment the organization gives the employee over time. (March \&Mannari 1977). Normative commitment is seen as the effect of the receipt of gains (which encourages an opinion that one should compensate) and/or acceptance of the term of a psychological contract.

\subsection{Relationship between Social Intelligence and Employee Commitment}

Greenspan, (1979) indicated that social intelligence enables psychological interpretation, signifying that socially intelligent people can justify other people's motivation and demonstration of behavior, understand personal characteristics, and interpret emotions. (Ford and Miura, 1983). This implies that workers with high degree of social intelligence can interpret and observe other people, which can be beneficial to the organization at large. Greenspan, (1979) further added that people with high social intelligence can showcase positive social communication and encourage other people's behavioral models to be more agreeable with their own needs. Research has proved that effective management increase commitment, productivity, mutual trust and loyalty of employees and will improve organizational productivity, job satisfaction, relative intelligence, integrity, team performance, innovation and organizational communication (Moghaddam et al, 2013). Social intelligence is for everyone who works in an organization, it is not specifically meant for only managers (Moghaddam et al, 2013). Malikeh and Fateme, (2012) contended that social intelligence is applying an awareness of the significant impact of relationships to help leaders enhance the performance of the people they are leading. Studies have unveiled that social intelligence also includes the ability to select an appropriate response and to be flexible on one's behavior (Robert 2008). Nonetheless, people who have not developed their social skills cannot effectively connect with others and may even disaffect or hurt those (Malikeh\&Feteme, 2012). 
Another study shows that social intelligence is the ability of people to relate to others, understand them, and interact effectively with them. (Marti, 2005). Managers need therefore to develop their level of social intelligence to enable them get along well with employees and make them cooperate with them. Managers with high social intelligence will be highly effective compared to those with low social intelligence. According to Albretch, (2006) people with high social Intelligence are nourishing while those with low social intelligence are toxic. Nourishing behavior induces the feeling of being appreciated, respected, competent and motivated among people. Toxic behavior induces the feeling of anger, frustration, and guilt or other negative and inadequate emotions among people. As an individual is exposed to a continuing pattern of toxic behavior, his or her Social intelligence level reduces, negatively affecting the ability of the individual to connect to people and to influence them effectively. A continuing pattern of nourishing behavior will lead to a higher degree of effective interaction with others and also to influence them effectively. He added that people with high social intelligence attract others to them, whereas those with low social intelligence repel others. He went further to explain that building up social intelligence among managers and professionals will promote collaboration, reduce conflict, and replace bigotry and polarization with understanding.

This applies to mangers as well, Mangers with high social intelligence nourish their employees by encouraging and rewarding them, this will foster good relationship in the workplace and also positively influence employee attitude to work. This will in turn positively affect the employee's commitment to work. Employees who are socially intelligent relate better with superior/subordinates in work places because of their interpersonal skills. Relationship in the workplace is critical to every organization be it public or private sector, it helps to reduce frustration amongst employees, low morale, low team spirit/shattered group cohesion and low job satisfaction. According to Albrecht, (2004) people learn as they grow, mature and gain experience in dealing with others. Unfortunately, many individuals only grow and do not learn or acquire the awareness and skills they require to succeed in social, business or professional situations. It is necessary to make employees realize that relationship is as important in the work place as work itself. Hampered relationship may lead to workers not been committed to their jobs with resultant effect of reduced productivity by the employees and ultimately poor performance by the organization. Commitment of employees is valued among employees in any organization because it is assumed that it reduces withdrawal behavior such as absenteeism, lateness and turnover which results to grievous outcomes that negatively affects overall organizational performance.

Ramayah, (2009) posited that employees with spirit of commitment are less likely to engage in withdrawal behavior and are more willing to accept change. When employees begin to lose the spirit of commitment to an organization, the implication is that it will be channeled to other directions; therefore managers should be charged with the responsibility of knowing how to develop the right kind and degree of employee commitment in organizations and to secure suitable and capable employees. Extremely committed employees tend to be majorly fulfilled and satisfied with their jobs. Eketu and Edeh (2015) found that managers need to be socially intelligent about the benefits of induction and training of employees' this they opined will make the employees more effective in their various jobs and this in effect will have a positive influence on the organization. However there seems to be a relationship between employee commitment and factors such as culture and reward. Furthermore the organizational cultural perception and attitude of workers in public sectors seems to have eaten away the need for commitment among the workforce (Ezirim, Nwibere\&Emecheta, 2010).

\subsection{Clarity and Employee Commitment}

The ability to communicate effectively has been linked to employees trust in their organizations leader (Sanders and Thornhill 2003). Leaders who display openness and engage in negotiation with those they manage; tend to effectively boost organizational goals (Bambacas \&Patrickson 2008). Whereas poor leader-follower relations reduce employee commitment, productivity can lead to other kinds of withdrawal behaviors such as absenteeism. Elements of communication process are said to be associated with employee affective and continuous commitment. Vance and Colella, (1990) proposed that feedback was a direct determinant of commitment. There is also evidence supporting the positive impact of instrumental communication on job satisfaction (Bhedom, 1982). Employees who are pre-informed of their task by their management tends to be more satisfied and committed to their jobs than employees who are not. Infant and Godon, (1993) found that employees who communicate with their superior management for pleasure report high satisfaction with those superior, this confirming their earlier conclusion (Infant and Gordon, 1991) that good communication climates lead to satisfaction and greater employee commitment. Eketu and Edeh, (2015) Managers and leaders must be able to express themselves clearly by effective use of language, communication should be clear to both superior and subordinates without barriers, explanation of concepts should be done clearly, managers should have the know-how to persuade their subordinates with good ideas in manners that employees will key into the goals of the organization. When employees' align themselves with organizations goals it helps in building mutual trust and commitment in the part of employees. Based on the foregoing, the related hypotheses are stated as follows: 
$\mathrm{Ho}_{1}$ There is no significant relationship between clarity and affective commitment of employees in the health sector in Nigeria.

$\mathrm{Ho}_{2}$ Clarity has no significant relationship with employee continuance commitment in the health sector in Nigeria.

$\mathrm{Ho}_{3}$ There is no significant relationship between clarity and normative commitment of employees in the health sector in Nigeria.

\section{Methodology}

This study adopted a survey approach with a population of 2220 staff. A sample size of 339 was determined using Taro Yemen's technique. A total of 339 respondents were administered questionnaires out of which 313 were retrieved, but 273 questionnaires were found useable representing $81 \%$ of the sample size used for analysis of the study. The instrument used for data collection was the questionnaire. The questionnaire was classified into two section. Section A deals with the demographic data while section B comprised of respondent opinion concerning the study variables. The questionnaire adopted the 5-piont Likert scale rating. The scale used for measuring Clarity was adapted from the work of Albretch (2006) and Goleman (2006). Employee Commitment was measured using Allen and Mayer (1990) the ECQ which was adapted for this study. The ECQ measured Affective Commitment, Continuance Commitment and Normative Commitment. The variables that were employed for this study were sourced from existing literature and had been pre-tested and validated in previous studies ( Albretch, 2006; Goleman, 2006; Allen and Mayer 1990). Therefore the variables had construct validity. Cronbach Alpha was used to test for reliability in our study. According to researchers (Bryman and Bell; Nunally 1978) an alpha level of 0.80 is generally accepted as a good level of internal reliability of the instrument, though an alpha level of 0.70 is also considered to be efficient. For test of reliability the following Cronbach Alpha Coefficient were obtained for our scales; Social Intelligent (0.701) and Commitment (0.726). Hence all our variables had internal reliability. Frequencies and percentages were used to classify our demographic data. Our variables were subjected to univariate and bivariate analysis. Inferential statistics using Spearman Rank Order Correlation Coefficient was used to establish the association between Social Intelligence and Employee Commitment.

\section{Data Analysis and Results}

Table 1. Clarity and Employee Commitment

\begin{tabular}{|c|c|c|c|c|c|c|}
\hline & Clarity & $\begin{array}{l}\text { Affective } \\
\text { Commitment }\end{array}$ & $\begin{array}{l}\text { Continuance } \\
\text { Commitment }\end{array}$ & $\begin{array}{l}\text { Normative } \\
\text { Commitment }\end{array}$ \\
\hline \multirow{12}{*}{$\begin{array}{l}\text { Spearman's } \\
\text { rho }\end{array}$} & \multirow[t]{3}{*}{ Clarity } & Correlation Coefficient & 1.000 & $.932^{* * *}$ & $.950^{* *}$ & $.940^{* * *}$ \\
\hline & & Sig. (2-tailed) & & .000 & .000 & .000 \\
\hline & & $\mathrm{N}$ & 273 & 273 & 273 & 273 \\
\hline & \multirow[t]{3}{*}{ AFC } & Correlation Coefficient & $.932^{* * 4}$ & 1.000 & $.965^{* *}$ & $.984^{* * *}$ \\
\hline & & Sig. (2-tailed) & .000 & . & .000 & .000 \\
\hline & & $\mathrm{N}$ & 273 & 273 & 273 & 273 \\
\hline & \multirow[t]{3}{*}{$\mathrm{CC}$} & Correlation Coefficient & $.950^{* *}$ & $.965^{* * *}$ & 1.000 & $.970^{* *}$ \\
\hline & & Sig. (2-tailed) & .000 & .000 & & .000 \\
\hline & & $\mathrm{N}$ & 273 & 273 & 273 & 273 \\
\hline & \multirow[t]{3}{*}{$\mathrm{NOC}$} & Correlation Coefficient & $.940^{* * *}$ & $.984^{* * *}$ & $.970^{* * *}$ & 1.000 \\
\hline & & Sig. (2-tailed) & .000 & .000 & .000 & \\
\hline & & $\mathrm{N}$ & 273 & 273 & 273 & 273 \\
\hline
\end{tabular}

\subsection{Relationship Between Clarity And Employee Affective Commitment}

$\mathrm{Ho}_{1}$ : There is no significant relationship between clarity and affective commitment of employee in the health sector in Nigeria. The statistical output on the first hypothesis reveals that there is a significant relationship between clarity and affective commitment (where rho $=.932 * *$ and $\mathrm{p}<0.05$ ) hence we find that clarity strongly associates with employee affective commitment in the health sector and based on the decision rule of $p<0.05$ for null rejection; we therefore reject the null hypothesis and restate that there is a significant relationship between clarity and affective commitment.

\subsection{Relationship between Clarity and Employee Cotinuance Commitment}

$\mathrm{Ho}_{2}$ : Clarity has no significant relationship with employee continuance commitment in the health sector of Nigeria. The bivariate output on the second hypothesis reveals that clarity significantly relates to continuance commitment of employee (where rho $=.950^{* *}$ and $\mathrm{p}<0.05$ ) hence we find that clarity strongly associate with employee 
continuance commitment and going by the decision rule of $\mathrm{p}<0.05$ for null rejection; we therefore reject the null hypothesis and restate that there is a significant relationship between clarity and continuance commitment in the health sector.

\subsection{Relationship between Clarity And Employee Normative Commitment}

$\mathrm{Ho}_{3}$ : There is no significant relationship between clarity and normative affection of employees' in the health sector of Nigeria. The third hypothesis was tested to examine the positive relationship between clarity and normative commitment of employee (where rho $=.940 * *$ and $\mathrm{p}<0.05$ ) hence we find that clarity strongly influence employee normative commitment and standing by the decision rule of $\mathrm{p}<0.05$ for null rejection; we therefore reject the null hypothesis by restating that clarity significantly relates to employee normative commitment in the health sector of Nigeria.

\section{Discussion of Findings}

The aim of this study was to examine the empirical relationship between social intelligent and employee commitment. The bivariate results on clarity and the three measures of commitment (affective, continuance and normative) indicates strong correlation between the variables. These results shows that well treated employees' in the health sector have moral obligation to pay back in return with hard work, total dedication and commitment to their employing organizations provided the organization expresses their intentions clearly in a language these employee's understand as appropriate. This results are supported by Brinkert (2010); Sanders and Thornhill (2003); Infant and Gordon (1991) who believed that communication shouldn't just be a medium of transmitting knowledge and or information from superior to subordinate but the link that should build mutual trust among member of the organization which will create a climate for greater commitment among the workforce. The implication here is that, if organizations creates an atmosphere of effective communication among its workforce, the employees will be bounded to reciprocate by ensuring the attainment of organizational goals but if the reverse becomes the case it leads to low morale, commitment and absenteeism.

\subsection{Conclusion and Recommendation}

In conclusion the study found that social intelligence influence employee commitment and thus enhances outcomes such as mutual trust, maintenance of high performance standards and achieving high performance goals. Clarity as a dimension of social intelligence is important for gaining employee's confidence as it build mutual trust among coworkers that creates a climate for greater commitment, productivity and performance. This can be attained if information is clearly passed to whom it is concerned using appropriate channels. As a result of the findings, summary and conclusions of the study, the following recommendations are herein proffered as ways in which employees' commitment in the health sector can be enhanced: Social intelligence skill when applied to leadership recognizes that, the most important activity of a leader is to connect with others in order to boost employee's performance. Therefore, leaders must ensure to apply the knowledge gained from these skills to correct workers wrong doings in the right manner as this will spur employee's morale, dedication, productivity as well as commitment, since they (leaders) can understand other people's ability, self-confidence and guide in decision making.

\subsection{Suggested For Further Studies}

This study investigated the relationship between social intelligence and employee commitment within certain specified theoretical, geographical and target scope; thus the generalization of the result of the study can only be specific to the health sector given the parameters wherewith it was carried out. As a result of this, we therefore suggest that effort be made to ascertain the validity of these results within other sectors, industries or national context.

\section{References}

Ahmed AbdulhameedAufan Al- Makahleh and Ayed Hanna Ziadat (2012). Social Intelligence and Personal Characteristics of Talented Secondary School Students in King Abdullah II schools for excellence, JordanEducational Research (ISSN: 2141-5161) Vol. 3 (10) pp 785-798, October 2012.

Akinbode A. G., Oni B., F (2012). Leadership and Organizational factors as Predictors of Employees Organizational Commitment in Nigeria: An Empirical Analysis, Business and Management research Vol. 1 No. 22012

Albrecht, K. (2006). Social Intelligence: The New Science of Success, San Francisco: Jossey- Bass.

Allen, N. J. \& Meyer, J. P. (1996). Affective, Continuance and Normative Commitment to the Organization: An Examination of Construct Validity. Journal of Vocational Behaviour, 49, pp 252-276.

Allen, N. J. and Meyer J.P. (1990). The Measurement and Antecedents of Affective Continuance and Normative Commitment to the Organization, Journal of Occupational Psychology. No 63. Vol. 1 pp 1-18. 
Baggiyam D.N. and Pankejam R. (2017). Social Intelligence in Relation to Academic Achievement International Journal of Research - Grannthaalayah, 5[3] SE, 18-22. http://doi.org/10-5281/Zenodo.545958.

Bambale J. A., mohd-shamsudin f., Subramanim C., and Ramalu S. 2012. Clarifying the Ambiguity Surrounding Organisational Citizenship Behaviour (OCB) and Related Behavioural constructs. International Journal on social Science Economics and Art Vol. 2 (2012) No. issue: 2088-5342

Becker, T. E., Randall, D. M \&Reigel, C.O,(1995). "The Multidimensional view of Commitment and the Theory of Reasoned Action; A Comparative Evaluation”. Journal of Management, 21(4) 616-639.

Becker, H. S (1960) Notes on the Concept of Commitment, American Journal of Sociology. No 66. Pp 89-296.

Birknevova Z, Frankorsky M., Zbililejora L (2013). Social Intelligence in the contest of Personality Traits of Teachers, American International Jornal of Contemporary Research, Vol 3. No. 7 July 2013.

Brinkert, R., (2010). A Literature Review of Conflict Communication Causes Cost, Benefits and Interventions in Nursing. Journal of Nursing Management, Vol. 18, pp. 145-156.

Coetzee m., Botha J., (2012). The Languishment of Employee Commitement in the light of perceptions of Fair Treatment in the Workplace: SA journal of Human Resource Management/SA TydskritVirMenslikehelpbronbestuur, 10(2), Art \# 436, 11 pages.

Dhanda, B.R, and NinaniyaP.. (2017). Dimensions of social Intellegence of Adolescents, 10SR Journal of Humanities and social Science (10SR-JHSS) volume 22, Issue 3, Verlll (march 2017) pp. $56-57$ e-IssN: 2229 -0837, PISSN 2229-0845.

Dixit, v., and Bhatt .M (2012). A study About Employee Commitment and its Impact on Sustained Productivity in Indian auto - component industry. European journal of business and social sciences Vol. 1 pp 34-51

Ebrahimpoor H, Zahed A and Elyasi A, (2013). The Study of Relationship Between Social Intelligence and Organisational Performance International Journal of Organisational Leadership 2013 (vol 2 No 1: 1-10).

Evans, R.G. (2003). Patient Centered Medicine: Reason, Emotion, and Human Spirit. Some Philosophical Reflections on being with Patients. Med Montly Jun 29(1): 8-14.

Goleman, D. (2006). Social Intelligence: The New Science of Human Relationships, New York Bantan Books ISBNO553803522.

Greenspan, S. (1979). Social Intelligence in the retarded. In N.R. Ellis (ED), Handbook of mental deficiency: Psychological Theory and Research (PP. 483-525).

Hrebiniak, L.G. and Alutto. J.A (1973). Personal Role-related Factors in the Development of Organizational Commitment. Administrative Science Quarterly. No. 17 - pp 555-572.

Igbeneghu B.I and popoola S.O., (2011). Influence of Locus of Control and Job Satisfaction or organizational commitment: A study of medical record Personnel in University Teaching Hospitals in Nigeria. Liberty Philosophy and practice (e-journal) $575 \mathrm{http} / / /$ digital commons .rl.edu//ibphilpras/575.

John P. Meyer and Elyse R. Maltin (2010). Employee Commitment and Well Being: A Critical Review, Theoretical Framework and Research Agenda. Journal of Vocational Behavior 77(2010) 323-337.

Jug V. (2015). Personality Traits, Social Intelligence, Social Support and Juvenile Delinquency, Procedure of the Third International Conference Advances in Social Sciences, Economics and Management Study SEM 2015 Copyright @ Institute of Research Engineer and Doctors, USA ISBN: 978-163248-063-7.

Lambrini, K. \&Loanna, V.P, (2014). Communication in Nursing Practice Professional Paper, Mater Socio-med Vol. 26 No. 1 pp 63-67.

Meyer, J.P. and Allen, N.J. (1991). A three Component Conceptualisation of Organizational Commitment: Human Resources Management Review No 1. pp 61-89

Meyer, J.P, Allen N.J., and Gellatly L. (1990). Affective and Continuance Commitment to the organization: Evaluation of measures and Analysis of Concurrent and Time Tagged Relations. Journal of Applied Psycology No. 75 pp 710-720.

Meyer, J. P., Allen N. J. (1997). Commitment in the workplace. Theory, Research and application. Thousand Oaks Sage.

Meyer, J. P. \&Herscoritch, L. (2001) Commitment in the workplace: Toward a general model. Human resources management reviews, 11, 299-326.

Mogheddam, A,G, Kemani, S. S , Gborbani, M., Sadeghi, FS .M.A Sardaribadi, P. (2013). The Relationship Between Social Intelligence of Managers and Performance of Brokerage Firms: Evidence from Tehran Stock Exchange. Interdisciplinary Journal of Contemporary Research in Business 681.vol 5: No 3.

Nunally, J-c (1978). Psychometric Theory ( $2^{\text {nd }}$ Edition ) New York mctrawhill.

Okpara, and Wynn Pamela (2008).”The Impact of Ethical Climate on Job Satisfaction and Commitment in Nigeria: Implications for Management Development”, Journal of Management Development Vol. 27 issue 9, pp 935950, https://doi. Org/10.1108/026 21210810901282 
Okpara J. O. (2004). Job satisfaction and organization commitment: Are there differences between American and Nigerian managers Employed in the us MNCS in Nigeria Research Galernet July 2004, 12-14

Olori W.O. and Dan Jumbo comfort (2017). Workplace Discrimination and Employee Commitment in Rivers State Civil Service, Nigeria. European Journal of Business and management ISSN 2222-1905: volume 9.No.8 2017.

Owoyemi, OluwakemiAyodeji, Oyelere Michael, Elegbede Tunde and Gbajumo-sheriff Miriam (2011). Enhancing Employees Commitment to Organisation through Training. International Journal of Business and Management Vol-6 No 7: July2011.

Patel H (2017). A Study of Social Intelligence Among Commerce and Science College Studies International Journal of Indian Psychology, Vol. 4 (13) DIP:18:01.220/20170403.

Saxena S. And Jain K.R( 2013). Social Intelligence of Undergraduate Students in Relation to their Gender and Subject Stream 10SR Journal of Research and method in Education (10SR JRME) Vol 1 Issue 1 (Jan - feb, 2013) PP01-04.

TarelaOkpu and seth Accra Jaja( 2014). Quality Circle and Workers Commitment in Nigerian Banking Industry International Journal of Development and Sustainability ISSN: $\quad$ 2168-8662- Volume 3 Number 4 (2014) pages 749-766 ISDS Article ID: IJDS13110602.

Vance, R.J. and Collella, A. (1990). Effects of two types of feedback on Goal acceptance and Personal goods. Journal of Applied Psychology. No 75. pp. 68-76. 